\title{
Life Cycle Assessment and Short-Term Measurements of Indoor Environmental Quality of a Wooden Family House
}

\author{
Silvia Vilčeková*, Katarína Harčárová, Andrea Moňoková, Eva Krídlová Burdová \\ Faculty of Civil Engineering, Technical University of Kosice, Kosice, Slovakia
}

Received 04 February 2020; accepted 31 March 2020

\begin{abstract}
Nowadays, there is an increased trend in the construction of nearly zero energy buildings which can be also characterized as green buildings. Several studies confirm that wooden buildings fulfil these requirements. However, there is no detailed research related to the quality of the indoor environment in new wooden family houses. For this reason, this paper focuses on monitoring of the indoor environmental quality in a selected wooden family house. Shortterm measurements are aimed at investigation of physical parameters (air temperature, relative humidity, air velocity and noise) and chemical factors such as concentrations of particulate matters and $\mathrm{CO}_{2}$. At the same time, environmental impacts were also assessed for impact categories such as: global warming potential (GWP), ozone depletion potential (ODP) acidification potential (AP), eutrophication potential (EP), photochemical ozone creation potential (POCP) expressed as kilogram $\mathrm{CO}_{2 \mathrm{eq}}, \mathrm{CFC}_{11 \text { eq }}, \mathrm{SO}_{2 \mathrm{eq}}, \mathrm{PO}_{4}{ }^{3-}$ eq and kilogram of $\mathrm{C}_{2} \mathrm{H}_{4 \mathrm{eq}}$ within "Cradle to Grave" boundary by using the life cycle assessment (LCA) method. The main contribution of this study is demonstration that wooden buildings have substantial share in the reduction of environmental impacts. So far, results indicate that the design of wooden houses correspond with the increasing demands of occupants in terms of environmental, social and energy performance.
\end{abstract}

Keywords: wooden house, indoor environment, air quality, energy performance, LCA.

\section{Introduction}

Climate change has often been considered the most significant current threat and thus most of global attention has been on climate change mitigation and resilience to warming. Buildings alone cause one third of the global anthropogenic greenhouse gas (GHG) emissions, and use approximately the same share of the global energy production. A study (Schmidt \& Osebold, 2017) states that construction activity introduces an essential role in socio-economic development of the country, as it provides infrastructure set-out, on which all sectors of economy firmly depend. Therefore, it makes the building industry one of the most strategic sectors. The development of science and research allows building industries to move forward in the development of new materials on different basis. Building materials are thus gaining another dimension. While in the past solely natural materials were used, nowadays a most of them are produced artificially and often by technologies that have considerable negative impacts on the environment. A part of the concept of sustainable development is the right choice of building materials for implementation of the selected object. By selection of environmentally friendly building materials a reduction in depletion of natural resources and factory emissions as well as creation of more suitable microclimate in building interior can be achieved (Green Technology, 2020; American Elements, 2020).

The study (Gustafsson et al., 2017) investigates the economic feasibility and environmental impact of energy renovation packages for European office buildings. The renovation packages, including windows, envelope insulation, heating, cooling and ventilation systems and solar photovoltaics (PV), were evaluated in terms of life cycle cost (LCC) and life cycle assessment (LCA) through dynamic simulation for different European climates. Compared to a purely functional renovation, the studied renovation packages resulted in up to $77 \%$ lower energy costs, $19 \%$ lower total annualized costs, $79 \%$ lower climate change impact, $89 \%$ lower non-renewable energy use, 66\% lower particulate matter formation and $76 \%$ lower freshwater eutrophication impact over a period of 30 years. The lowest total costs and environmental impact, in all of the studied climates, were seen for the buildings with the lowest heating demand. Solar PV panels covering part of the electricity demand could further reduce the environmental impact and, at least in southern Europe, even reduce the total costs (Gustafsson et al., 2017).

*Corresponding author. E-mail: silvia.vilcekova@tuke.sk 
With the growing construction of wooden houses, the question arises whether wood as an environmentally friendly construction and building material creates a better indoor environmental quality compared to houses with traditional construction. The previous studies suggest that in terms of internal microclimate, wooden buildings are a better alternative to traditional brick or concrete houses. The most significant differences were observed in the case of $\mathrm{CO}_{2}$ concentration and relative humidity in favor of wooden buildings (Sviták et al., 2018). In the context of wooden construction, the trend of building energy-efficient and passive houses that provide a better indoor environment is gradually increasing (Derbez et al., 2014; Langer et al., 2015).

The main objective of this work is to evaluate the life cycle of the selected wooden building and to assess whether this wooden building provides a healthy indoor environment for the occupants themselves.

\section{Object}

Assessed family house was built in 2006 in the village Rozhanovce, Eastern Slovakia. Its bearing system consists of a timber frame filled with thermal insulation of mineral wool thickness of $140 \mathrm{~mm}$. From the exterior it is covered with OSB boards with silicate plaster. The interior surfaces of the bearing walls are made of plasterboard. For partition walls aerated concrete blocks were used. The load-bearing structure of the roof is made of rafter system, saddle shape. It is insulated with mineral wool of thickness $250 \mathrm{~mm}$. The floor structures on the first floor are hard floating with a finish layer of laminate and ceramic tiles. In the attic on the timber beamed ceilings, the floors are made as light, from OSB boards with laminate surface treatment. The foundation structures are formed by concrete foundation strips, which are insulated with XPS thickness of $80 \mathrm{~mm}$. This family house is connected to all public utilities. A gas boiler is used for space and water heating. The fully enclosed covered area is $145 \mathrm{~m}^{2}$. Its energy demands for space heating and hot water preparation are $96.55 \mathrm{kWh} / \mathrm{m}^{2}$ per year and $2800 \mathrm{kWh}$ per year, respectively. The exact location and view of the assessed wooden family house are depicted in Figure 1.
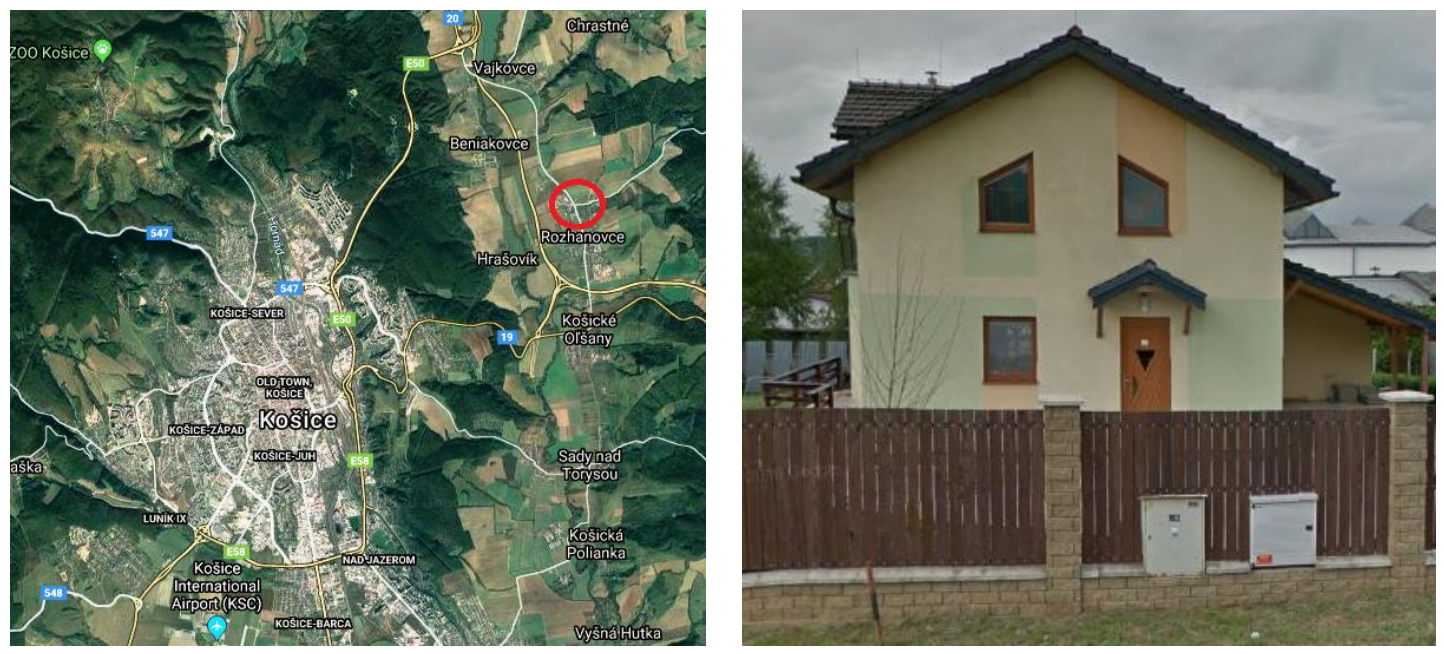

Figure 1. Location and view of wooden family house

\section{Methods}

\section{Life cycle assessment}

Environmental performance of wooden family house is calculated by using the LCA assessment method within "cradle to grave" boundaries according to the recommendations of EN 15978. Life cycle assessment is a standardized tool used to assess and report relevant environmental impacts of a product's life cycle. The LCA framework is interpreted in EN ISO series 14040-44. The eToolLCD software was used for the LCA assessment, which is compliant with the CML-IA methodology v4.5 (Hermon, 2017). A reference study period of 60 years was considered. The functional unit in this study is defined as one square meter of fully enclosed floor area for a period of the life cycle $\left(1 \mathrm{~m}^{2}\right)$. Software eToolLCD allows by Life-Cycle Assessment to evaluate the effect on the environment of a product, service, or process over its entire life-cycle. This means that LCA takes into consideration all the steps that lead from raw material to manufactured product, including extraction of the materials, energy consumption, manufacture, transportation, use, recycling, and final disposal or end of life. It is a holistic methodology that quantifies how a product or process affects climate change, non-renewable resources, and the environment as a whole. 


\section{Measurements of indoor environmental parameters}

Indoor environmental quality (IEQ) monitoring devices were located approximately in the center of the living room at a height of $1.1 \mathrm{~m}$ above the floor. Air monitoring was carried out for 1 hour when the occupants were at home and in the room where they spend most of their time together. Measurements were performed in the presence of 3 adults and without disturbing the natural running of the household. The values of air temperature, relative humidity, air velocity and $\mathrm{CO}_{2}$ concentrations were recorded using a TESTO 435-4 multifunction measuring instrument with appropriate probes (Testo, Inc.; Germany). A hand-held noise analyser - Brüel and Kjaer Type 2250, from Brüel and Kjaer; Denmark, was used to measure the acoustic sound levels. The concentrations of particulate matters (PM) were measured over a range of fractions 0.5 to 10 micrometers using a HANDHELD 3016 IAQ (Lighthouse Worldwide Solutions, Inc., USA) measuring instrument. Indoor air temperature, relative humidity, $\mathrm{CO}_{2}$ concentrations and concentrations of particulate matters were recorded at one-minute intervals. Acoustic sound levels were recorded at 15 minutes' intervals. All measurements were carried out in the cold period during the heating season.

\section{Results and discussion}

\section{Result of life cycle assessment}

Based on the design documentation of the wooden building was found material composition of the wooden house and according to it was developed model LCA building. Based on the thermal insulation properties of house and its energy efficiency certificates, a model of operation of house for 60 years was developed. End of life cycle, house demolition and material and energy recovery of used materials were also included in LCA model.

Because of comparison for evaluation purposes of environmental impact assessment the results of other studies focused on the evaluation of masonry buildings were used (Moňoková \& Vilčeková, 2019). In terms of the construction of buildings, it was found that in comparison with masonry buildings timber construction have lower environmental impacts in almost all categories except the global warming impact (GWP) category. Although the timber construction in the construction stage (A1-A3) of the house shows lower results in most impact categories, the differences in most categories are not high. In the case of the use of building materials after the demolition of buildings and in the case of the energy use of wooden parts, the environmental impacts of the construction and demolition together are comparable for both types of buildings.

The results of environmental impacts for individual stages of the life cycle of assessed wooden family house are presented in Table 1. A major risk is the creation of greenhouse gases, the concentration of which in the atmosphere causes global climate change. The selected key indicators are GWP, ODP, AP, EP and POCP.

Table 1. Environmental impact indicators for each stage

\begin{tabular}{|c|c|c|c|c|c|c|c|c|c|c|}
\hline \multirow{2}{*}{ Impact } & \multicolumn{3}{|c|}{ Materials and construction } & \multicolumn{5}{|c|}{ Use stage } & \multirow{2}{*}{$\begin{array}{c}\text { End of life } \\
\text { stage }\end{array}$} & \multirow{2}{*}{ Total } \\
\hline & $\mathrm{A} 1-\mathrm{A} 3$ & A4 & A5 & B1 & $\mathrm{B} 2$ & B5 & B6 & B7 & & \\
\hline $\mathrm{GWP}[\mathrm{kg} \mathrm{CO} 2 \mathrm{eq}]$ & 62.00 & 15.00 & 8.10 & 0 & 0.076 & 54.00 & 1500 & 26.00 & 8.50 & 1700 \\
\hline $\mathrm{ODP}\left[\mathrm{kgCFC}_{11 \mathrm{eq}}\right]$ & $0.72 \mathrm{E}^{-5}$ & $0.99 \mathrm{E}^{-6}$ & $0.49 \mathrm{E}^{-6}$ & 0 & $0.39 \mathrm{E}^{-8}$ & $0.68 \mathrm{E}^{-5}$ & $0.27 \mathrm{E}^{-5}$ & $0.14 \mathrm{E}^{-5}$ & $0.38 \mathrm{E}^{-8}$ & $0.20 \mathrm{E}^{-4}$ \\
\hline $\mathrm{AP}[\mathrm{kg} \mathrm{SO} \mathrm{Seq}]$ & 0.79 & 0.035 & 0.067 & 0 & $0.36 \mathrm{E}^{-3}$ & 0.84 & 0.46 & 0.13 & 0.15 & 2.5 \\
\hline $\mathrm{EP}\left[\mathrm{kg}\left(\mathrm{PO}_{4}\right)^{3-}{ }_{\mathrm{eq}}\right]$ & 0.16 & $0.77 \mathrm{E}^{-2}$ & 0.014 & 0 & $0.81 \mathrm{E}^{-4}$ & 0.082 & 0.11 & 0.031 & 0.061 & 0.46 \\
\hline POCP $\left[\mathrm{kg} \mathrm{C} 2 \mathrm{H}_{4 \mathrm{eq}}\right]$ & 0.11 & $0.66 \mathrm{E}^{-2}$ & 0.01 & 0 & $0.2 \mathrm{E}^{-4}$ & 0.058 & 0.058 & $0.77 \mathrm{E}^{-2}$ & $0.61 \mathrm{E}^{-2}$ & 0.26 \\
\hline
\end{tabular}

Notes: Global warming potential (GWP), Ozone depletion potential (ODP), Acidification potential (AP), Eutrophication potential (EP), Photochemical ozone creation potential (POCP)

Selected phases are:

\begin{tabular}{|c|c|c|c|c|c|}
\hline A1 & Raw Material Extraction & B1 & Use & $\mathrm{C} 4$ & Disposal \\
\hline A2 & Raw Material Transport & B2 & Maintenance & & \\
\hline A3 & Product Manufacturing & B5 & Refurbishment & & \\
\hline A4 & Product/Equipment Transport & B6 & Integrated Operational Energy & & \\
\hline A5 & Construction - Installation & B7 & Operational Water & & \\
\hline
\end{tabular}

Based on several studies (Moňoková \& Vilčeková, 2019; Moňoková et al., 2019; Kamali et al., 2019; Schlegl et al., 2019), materials such as concrete structures, which constitute 18-25\% of the entire conventional building, have the highest global warming potential. The aerated concrete blocks, concrete roof tiles, thermal insulation boards (expanded polystyrene EPS, extruded polystyren XPS), polypropylene (PP) and polyvinyl chloride (PVC) also contribute a large proportion. In this research, the main contributors to the impacts are the foundation structures, plasterboards, thermal insulation and waterproofing. 
The following Figures 2-6 illustrate all environmental impact categories for selected stages of the life cycle of the family house.This enables a detailed understanding of what is responsible for the greatest environmental burdens. The system boundary was narrowed to phases most probably different for each studied house.

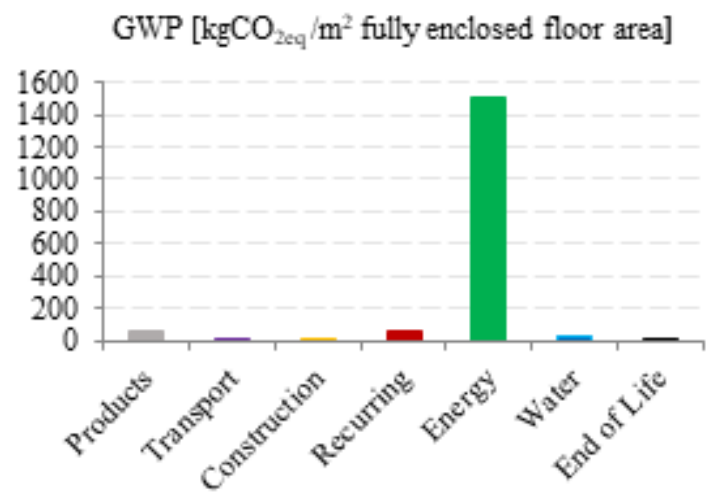

Figure 2. Environmental impacts of GWP

$\mathrm{AP}\left[\mathrm{kgSO} \mathrm{keq} / \mathrm{m}^{2}\right.$ fully enclosed floor area]

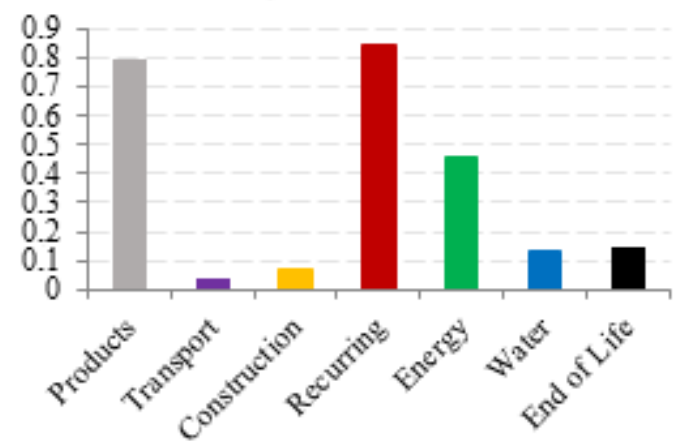

Figure 4. Environmental impacts of AP
$\mathrm{ODP}\left[\mathrm{kgCFC} \mathrm{Ileq}_{\mathrm{g}} / \mathrm{m}^{2}\right.$ fully enclosed floor area $]$

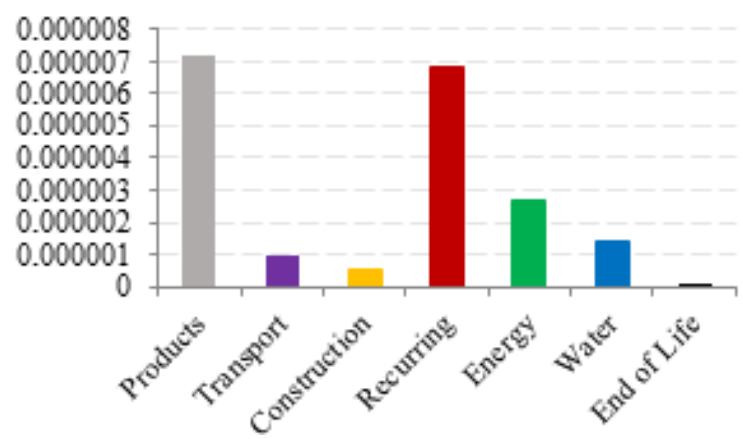

Figure 3. Environmental impacts of ODP

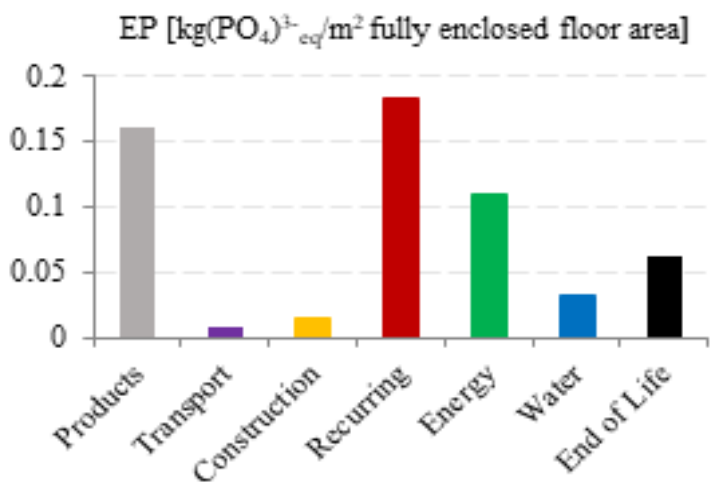

Figure 5. Environmental impacts of EP

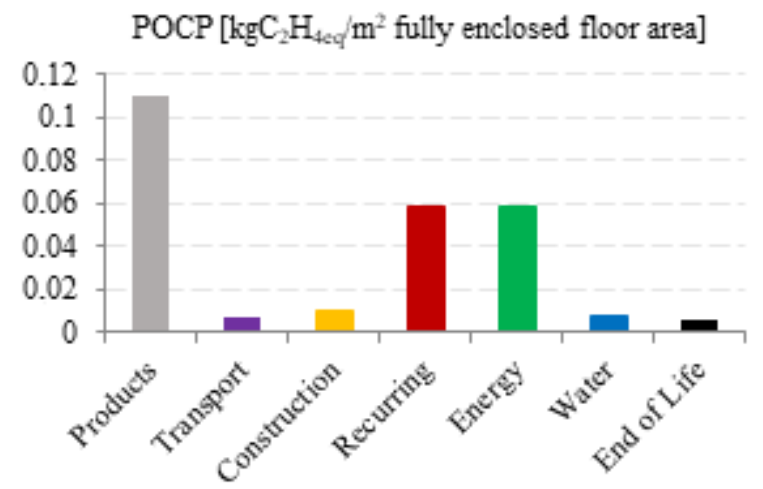

Figure 6. Environmental impacts of POCP

\section{Results of indoor environmental quality measurements}

Statistical evaluation of the IEQ parameters is given in Table 2. The obtained results were compared with the limit values approved by the Decrees of the Ministry of Health of the Slovak Republic No. 210/2016 and $115 / 2006$. 
Table 2. Statistical evaluation of IEQ parameters

\begin{tabular}{|c|c|c|c|c|c|c|c|}
\hline Statistics & $\begin{array}{c}\text { Indoor air temperature } \\
{\left[{ }^{\circ} \mathrm{C}\right]}\end{array}$ & $\begin{array}{c}\text { Relative humidity } \\
{[\%]}\end{array}$ & $\begin{array}{c}\text { Air velocity } \\
{[\mathrm{m} / \mathrm{s}]}\end{array}$ & $\begin{array}{c}\mathrm{CO}_{2} \\
{[\mathrm{ppm}]}\end{array}$ & $\begin{array}{c}\mathrm{PM}_{2.5} \\
{\left[\mu \mathrm{g} / \mathrm{m}^{3}\right]}\end{array}$ & $\begin{array}{c}\mathrm{PM}_{10} \\
{\left[\mu \mathrm{g} / \mathrm{m}^{3}\right]}\end{array}$ & $\begin{array}{c}\mathrm{L}_{\text {Aeq }} \\
{[\mathrm{dB}(\mathrm{A})]}\end{array}$ \\
\hline Average & 24.6 & 32.5 & 0.04 & 866.2 & 9.9 & 30.6 & 63.5 \\
\hline $\min$ & 23.3 & 26.0 & 0 & 754.9 & 8.9 & 23.3 & 60.9 \\
\hline $\max$ & 25.0 & 34.5 & 0.2 & 931.0 & 11.8 & 45.9 & 70.6 \\
\hline Standard deviation & 0.4 & 1.6 & 0.04 & 43.4 & 0.7 & 5.6 & 3.3 \\
\hline
\end{tabular}

During the measurement, the heating system of the house was active, which resulted in a movement of temperatures in the range from 23.3 to $25^{\circ} \mathrm{C}$. Relative humidity values ranged from $26 \%$ to $34.5 \%$. Based on these results, it can be stated that in the indoor environment of the monitored house there was a slight overheating of the indoor air. This fact could also be reflected in reduced values of relative humidity. As the natural running of the household was not disturbed during the measurement, a drop in temperature was observed for a short time during the measurement due to the opening of the front door. Otherwise, the windows and doors were closed during the measurement. The average values of air temperature and relative humidity were $24.6{ }^{\circ} \mathrm{C}$ and $32.5 \%$. It is clear from Figure 7 that the relative humidity values did not change significantly during the hourly interval and mostly fluctuated around the lower limit of the required legislative range of $30-70 \%$. The average air velocity did not exceed the permissible value of $0.2 \mathrm{~m} / \mathrm{s}$.

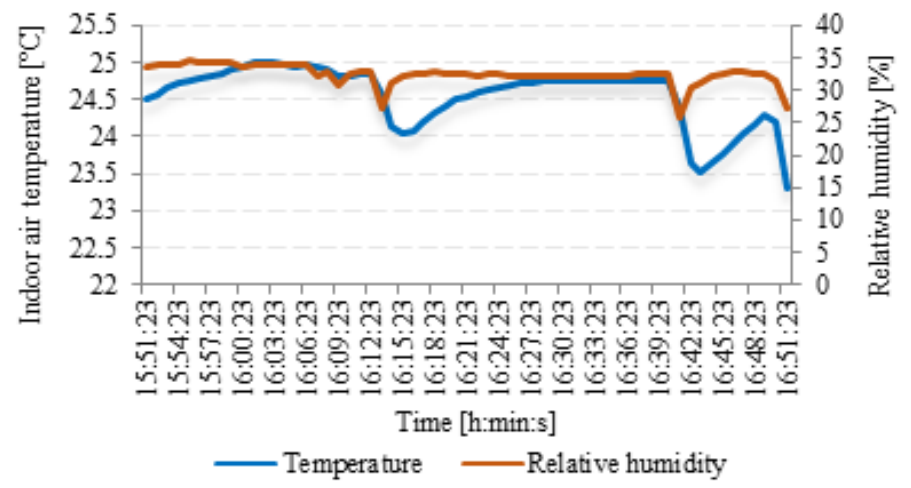

Figure 7. The course of indoor air temperature and relative humidity in the wooden family house

As can be seen in Figure 8, the concentration of the lower fractions was predominantly constant compared to the concentrations of the upper fractions, which fluctuated during the measurement. The concentrations of $\mathrm{PM}_{2.5} \mathrm{ranged}$ from $8.9 \mu \mathrm{g} / \mathrm{m}^{3}$ to $11.8 \mu \mathrm{g} / \mathrm{m}^{3}$ during hourly measurements and $\mathrm{PM}_{10}$ concentrations ranged from $23.3 \mu \mathrm{g} / \mathrm{m}^{3}$ to $45.9 \mu \mathrm{g} / \mathrm{m}^{3}$. The decree of the Ministry of Health No. $210 / 2016$ states a limit value $\left(50 \mu \mathrm{g} / \mathrm{m}^{3}\right)$ only for the $\mathrm{PM}_{10.0}$ fraction during 24-hour exposure. This required limit value was not exceeded during the entire short-term measurement.

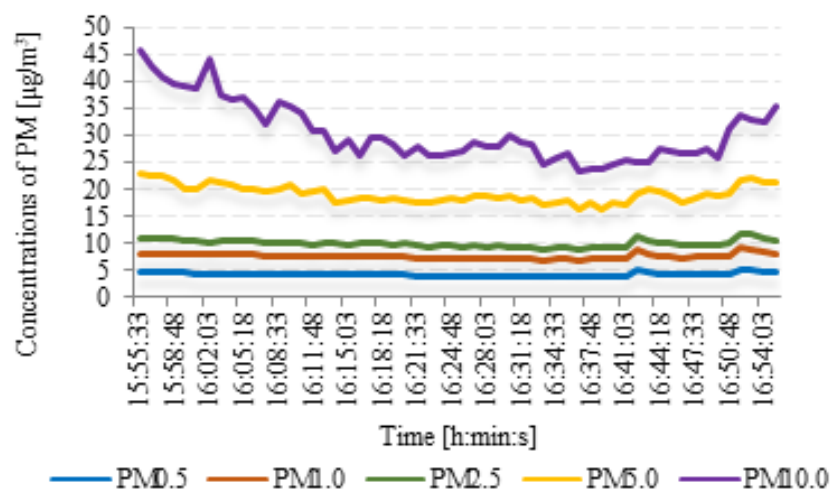

Figure 8. The course of $\mathrm{PM}_{0.5}-\mathrm{P} \mathrm{M}_{10}$ concentrations in wooden family house

The course of $\mathrm{CO}_{2}$ concentration, as shown in Figure 9, was also almost constant and did not exceed the recommended value of $1000 \mathrm{ppm}$ (Pettenkofer, 1858). The average $\mathrm{CO}_{2}$ concentration reached $866.2 \mathrm{ppm}$, which represents a $13 \%$ difference from the recommended value given by Pettenkofer. In this case, this value was mainly influenced by the number of people in the room, but also by the reduced air exchange in the winter season. 


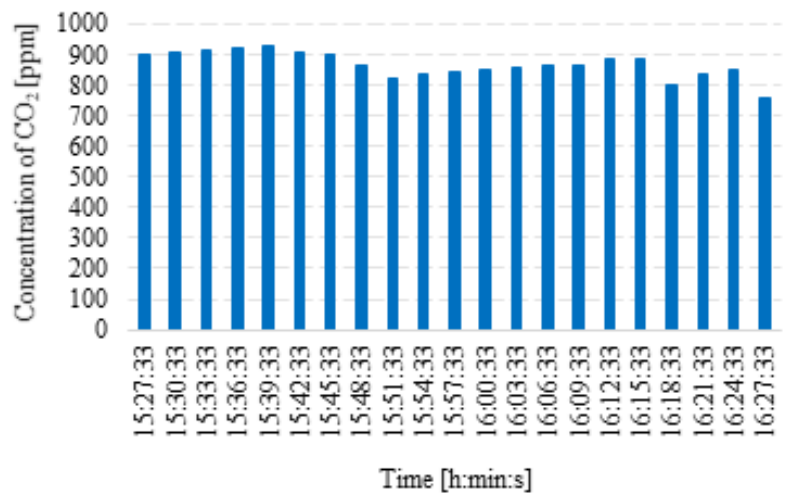

Figure 9. The course of $\mathrm{CO}_{2}$ concentrations in wooden family house

The value of equivalent sound level $\left(\mathrm{L}_{\text {Aeq }}\right)$ was $63.5 \mathrm{~dB}$, which represents a $37 \%$ exceedance of the $40 \mathrm{~dB}(\mathrm{~A})$ allowed value. On the basis of the above it can be stated that the monitored chemical parameters of the indoor environment meet the requirements given by legislation and selected wooden construction does not represent an environment with a negative impact on human health.

\section{Conclusions}

Wooden house (a building with a timber support system) represents a significant potential in eliminating environmental burdens in the context of applied building materials and has a high predisposition to meeting the objectives of an environmental strategy. In the coming years it is expected to increase the use of wood as the main building material, not only because of the environmental quality, but also the possibility of a close connection with nature and the creation of a healthy environment. The choice of building materials can have multiple impacts on energy consumption and related GHG emissions at different stages of its life cycle. The effects may be contradictory because, for example, high insulation thicknesses can contribute to energy savings during operation but also increase coupled energy. Embeded environmental impacts are not yet taken into account in the current requirements for the construction of new buildings. However, ensuring a balance of these factors is important. The right choice of building materials in the building design process plays an important role throughout the building's lifecycle and can have a significant impact on meeting sustainability principles. The main advantage of wooden skeleton is that the distinctive part of the subtle cladding consists of thermal insulation, which contributes to its high thermal resistance. Among the most important advantages belong speed of construction, while maintaining the required quality and dry manufacturing process. At the same time, wooden buildings meet the requirements of sustainable development and life cycle assessment, which will be an important indicator taken into account in the selection of building materials.

This case study also points to the quality of the indoor environment of a selected wooden-framed house. Due to the switching on of the heating system, a slight overheating of the interior spaces was recorded in the assessed house. By comparing the measured results of the selected chemical parameters (carbon dioxide and particulate matter concentrations) with the recommended and legaslative values, it can be stated that the indoor air in the selected wooden building does not cause discomfort and has no significant negative impact on the health of its occupants. In the future our research work will be the indoor environmental quality monitoring in wooden family houses to identify and compare the quality of the indoor environment in family houses built from different building materials and structures.

\section{Acknowledgements}

This paper was financially supported by the Slovak Grants, projects No. 1/0512/20 and 1/0648/17.

\section{Contribution}

Silvia Vilčeková had the original idea and design of the study. Andrea Moňoková and Katarína Harčárová carried out measurements and analysed data. Silvia Vilčeková, Andrea Moňoková and Katarína Harčárová interpreted the results, prepared the text, and provided the final version of the manuscript. Eva Krídlová Burdová revised the paper. All authors read and approve the final manuscript.

\section{Disclosure statement}

Authors declare that not have any competing financial, professional, or personal interests from other parties. 


\section{References}

American Elements. (2020). About green technology. Climate change. https://www.americanelements.com/green-technologyalternative-energy.html

Derbez, M., Berthineau, B., Cochet, V., Lethrosne, M., Pignon, C., Riberon, J., \& Kirchner, S. (2014). Indoor air quality and comfort in seven newly built, energy-efficient houses in France. Building and Environment, 72, $173-187$. https://doi.org/10.1016/j.buildenv.2013.10.017

Green Technology. (2020). Green technology - what is it? https:/www.green-technology.org/green-technology-what-is-it/

Gustafsson, M., Dipasquale, C., Poppi, S., Bellini, A., Fedrizzi, R., Bales, C., Ochs, F., Sié, M., \& Holmberg, S. (2017). Economic and environmental analysis of energy renovation packages for European office buildings. Energy and Buildings, 148, 155165. https://doi.org/10.1016/j.enbuild.2017.04.079

Hermon, P. (2017). eTool. Life cycle assessment. Office presentation example, isetta square, eToolLCD.

Kamali, M., Hewage, K., \& Sadiq, R. (2019). Conventional versus modular construction methods: A comparative cradle-to-gate LCA for residential buildings. Energy and Buildings, 204, 109479. https://doi.org/10.1016/j.enbuild.2019.109479

Langer, S., Bekö, G., Bloom, E., Widheden, A., \& Ekberg, L. (2015). Indoor air quality in passive and conventional new houses in Sweden. Building and Environment, 93, 92-100. https://doi.org/10.1016/j.buildenv.2015.02.004

Ministry of Health, Slovak Republic. (2006). Minimum health and safety requirements for the protection of workers against the risks of exposing to noise (Governmental regulation No. 115/2006 Coll. 2006).

Ministry of Health, Slovak Republic. (2016). Detailed requirements for indoor environment of buildings and minimum requirements for low-standard flats and accommodation facilities (Governmental regulation No. 210/2016 Coll. 2016).

Moňoková, A., \& Vilčeková, S. (2019). Environmental impact analysis of five family houses in Eastern Slovakia through a life cycle assessment. Selected Scientific Papers-Journal of Civil Engineering, 14(1), 81-92. https://doi.org/10.1515/sspjce-2019-0009

Moňoková, A., Vilčeková, S., \& Selecká, I. (2019). Life cycle analysis of single family houses and effects of green technologies on environment. Proceedings, 16(1), 1-4. https://doi.org/10.3390/proceedings2019016019

Pettenkofer, M. V. (1858). Über den Luftwechsel in Wohngebäuden. Literarischartistische Anstalt der Cotta'schen Buchhandlungen.

Schlegl, F., Gantner, J., Traunspurger, R., Albrecht, S., \& Leistner, P. (2019). LCA of buildings in Germany: Proposal for a future benchmark based on existing databases. Energy and Buildings, 194, 342-350. https://doi.org/10.1016/j.enbuild.2019.04.038

Schmidt, J. S., \& Osebold, R. (2017). Environmental management systems as a driver for sustainability: State of implementation, benefits and barriers in German construction companies. Journal of Civil Engineering and Management, 23(1), 150-162. https://doi.org/10.3846/13923730.2014.946441

Sviták, M., Krontorád, K., Kropáček, J., Hlásková, L., \& Solař, A. (2018). Parameters of indoor air quality (IAQ) in wooden houses. BioResources, 13(4), 8222-8238. https://doi.org/10.15376/biores.13.4.8222-8238 